\title{
Manuka Honey: A Potent Cariostatic Agent- An in vitro Study
}

\author{
1 Javaregowda P Beena, ${ }^{2}$ Punyatoya Sahoo, ${ }^{3}$ Sapna Konde, ${ }^{4} \mathrm{~N}$ Sunil Raj, ${ }^{5}$ Narayana C Kumar, ${ }^{6}$ Manisha Agarwal
}

\begin{abstract}
Aim: The aim of the study was to test the antibacterial activity of manuka honey and compare its efficacy with another commercially available honey (Dabur honey) on the cariogenic bacteria on Streptococcus mutans and Lactobacillus.

Materials and methods: An in vitro study was carried out on 40 agar specimens; the samples were divided into two groups of 20 samples consisting of $S$. mutans and Lactobacillus respectively. The 20 samples in each group were further subdivided into four groups of five each, which were tested with 25\% manuka honey, 100\% manuka honey, 25\% Dabur honey, and 100\% Dabur honey for both Lactobacillus and S. mutans groups. The antibacterial activity was tested using the agar well diffusion method against $S$. mutans and Lactobacillus. Antibacterial activity was assessed by measuring the diameter of inhibition of zones surrounding the wells. The results obtained were statistically analyzed (one-way analysis of variance test, p-value).
\end{abstract}

Results: The results showed that $25 \%$ of manuka honey has statistically significant $(p \leq 0.001)$ antibacterial effect than $25 \%$ of Dabur honey on both Streptococcus and Lactobacillus species, and manuka honey with $100 \%$ concentration showed a statistically significant ( $p \leq 0.001)$ antibacterial effect than $100 \%$ Dabur honey on the same species of bacteria. $100 \%$ of both the honeys showed statistically significant $(p \leq 0.001)$ antibacterial effect than $25 \%$ concentrations of the same on S. mutans and Lactobacillus.

Conclusion: Manuka honey had more antibacterial activity than Dabur honey on S. mutans and Lactobacillus bacteria in the in vitro study. This effect was dependent on the concentration of honey used.

Keywords: Antibacterial, Dabur honey, Lactobacillus, Manuka honey, Streptococcus mutans.

How to cite this article: Beena JP, Sahoo P, Konde S, Raj SN, Kumar NC, Agarwal M. Manuka Honey: A Potent Cariostatic Agent-An in vitro Study. Int J Clin Pediatr Dent 2018;11(2):105-109.

Source of support: Nil

Conflict of interest: None

${ }^{1,6}$ Reader, ${ }^{2}$ Postgraduate Student, ${ }^{3}$ Professor and Head ${ }^{4,5}$ Professor

${ }^{1-6}$ Department of Pedodontics and Preventive Dentistry, AECS Maaruti College of Dental Sciences \& Research Center Bengaluru, Karnataka, India

Corresponding Author: Javaregowda P Beena, 47, 9th Cross 29th Main Ist Phase, J.P. Nagar, Bengaluru-560078, Karnataka India, Phone: +919886442700, e-mail: drbeena.jp@gmail.com

\section{INTRODUCTION}

Honey has been used since the time of the ancient Egyptians, the Hebrew kingdoms, and historically in China, India, Greece, Rome, and many other nations. ${ }^{1}$ It is considered as an alternative medicine due to many health benefits attributed to it. ${ }^{2}$ Emphasis in this section is placed on the antibacterial properties of honey. Honey is produced by bees from the nectars they collect from flowers. When a bee collects nectar from flowers, it secretes into it enzymes from its pharyngeal gland. There are generally two varieties of honey, monofloral and polyfloral. Monofloral means it is sourced from one species of flora. The honey which is produced from the pollen and nectar from several species of flora is known as polyfloral honey. ${ }^{3}$

The antibacterial property of honey was first recognized in 1892 by Van Ketel. It has often been assumed that this is due entirely to the osmotic effect of its high sugar content. The fact that the antibacterial properties of honey increased when diluted was clearly observed and reported in 1919. ${ }^{4}$ The explanation for this apparent paradox came from the finding that honey contains an enzyme that produces hydrogen peroxide when diluted. This agent was referred to as "inhibine" prior to its identification as hydrogen peroxide. ${ }^{5}$

The research has proven that honey not only aids in inhibiting the growth of dental plaque bacteria but also significantly reduces the amount of acid produced. More specifically, it hinders the bacteria from producing dextran. ${ }^{6}$

Numerous studies have reported comparison of different varieties of honey, such as wildflower honey which are produced from the pollen and nectar of several species of flora, and the honey has an inhibitory effect on around 60 species of bacteria including Grams, aerobes, and anaerobes. A wide range of antifungal activity has also been observed including some species of yeast, aspergillus, and common dermatophytes. ${ }^{7}$

Numerous varieties of honey are produced all over the world and the medical properties of each of these reflect the particular floral source native to that place. Manuka honey is made by bees. The bees collect pollen from the flowers of Leptospermum scoparium tree. The honey cannot be called as such unless at least $70 \%$ of pollen it is made of comes from the manuka tree. The Aboriginal people have harnessed the benefits of the manuka honey for 
centuries. They grow wild in most parts of New Zealand but are especially seen in coastal areas. ${ }^{8}$

The manuka flower only blooms for a period of 6 weeks in spring season ${ }^{9}$ and is often region-specific. ${ }^{10,11}$ About $70 \%$ of manuka honey is of simple sugars like glucose and fructose and the rest is comprised of complex carbohydrates. ${ }^{12}$ However, the water composition of manuka honey is similar to other varieties of honey.

One factor that makes manuka honey stand out is its compound called methylglyoxal, which is quintessential for its antibacterial, antifungal, antimicrobial, and antiseptic properties. The levels of methylglyoxal present in manuka honey are considered a measure of its potency and purity. Hence, a unique manuka factor (UMF) rating system was developed to measure the level of methylglyoxal, and higher the level, higher the rating. ${ }^{13}$ Manuka honey with a rating below 10 is considered as effective as any regular honey.

Hence, the aim of the study was to test the antibacterial activity of manuka honey and compare its efficacy with another commercially available honey on the cariogenic bacteria.

\section{MATERIALS AND METHODS}

An in vitro study was carried out on 40 agar specimens; the samples were divided into two groups of 20 samples consisting of $S$. mutans and Lactobacillus respectively. The 20 samples in each group were further subdivided into four groups of five each, which were tested with $25 \%$ manuka honey, 100\% manuka honey, 25\% commercially available honey, and 100\% commercially available honey for both specimens.

\section{Assay of Antibacterial Activity}

The honey samples were tested for their antibacterial activity, according to the agar well-diffusion method proposed by the Clinical and Laboratory Standards Institute (CLSI) against the two reference strains: (1) S. mutans and (2) Lactobacillus species. The above bacteria were grown $(100 \mathrm{~mL})$ in trypticase soy broth at $37^{\circ} \mathrm{C}$ for 18 hours.

The honey concentrations $(\mathrm{w} / \mathrm{v})$ were prepared in sterile saline solution, 25, 100\%, and their antibacterial activity was evaluated against the bacterial strains. Thus, $100 \mathrm{~mL}$ aliquot of honey dilution was added to each well of blood agar inoculated with bacterial concentration which is similar to $0.5 \mathrm{McF}$ arland tube and incubated at $37^{\circ} \mathrm{C}$ for 24 hours.

Antibacterial activity was assessed by measuring the diameter of the inhibition zones surrounding the wells. Control plates were prepared with no honey added. All assays were repeated 10 times for each honey concentration.

\section{RESULTS}

Comparison of the inhibition zones of 25 and $100 \%$ Dabur and manuka honey showed statistically significant differences. Independent sample t test was used to compare the means between groups.

Table 1 shows that 25\% Dabur honey (Fig. 1) has less inhibitory effect than $25 \%$ manuka honey in S. mutans zone (Fig. 2) with a significant $\mathrm{p}$-value ( $\mathrm{p} \leq 0.001)$.

Table 2 shows that 100\% of Dabur honey (Fig. 3) has less inhibitory effect than $100 \%$ manuka honey in S. mutans (Fig. 4) with a significant $\mathrm{p}$-value ( $\mathrm{p} \leq 0.001)$.

Table 1: Comparison of mean zone of inhibition for S. mutans between Dabur (25\%) and manuka (25\%) honey

\begin{tabular}{lllllll}
\hline Organism & Honey & Mean & Standard deviation & Mean difference & t-value & $p$-value \\
\hline \multirow{2}{*}{ S. mutans } & Dabur 25\% & 9.8 & 1.5 & -4.6 & -7.48 & $<0.001$ (Significant) \\
& Manuka 25\% & 14.4 & 1.3 & & & \\
&
\end{tabular}

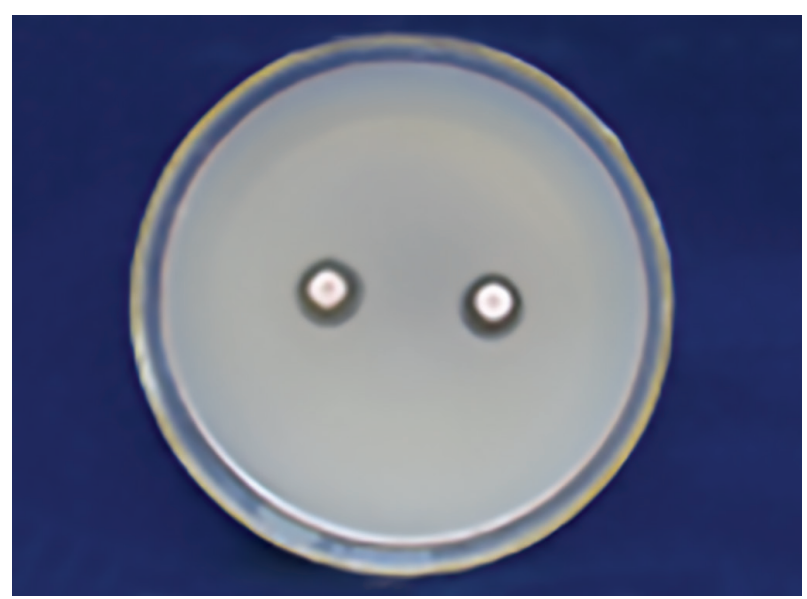

Fig. 1: Dabur honey zone of inhibition $25 \%$ (S. mutans)

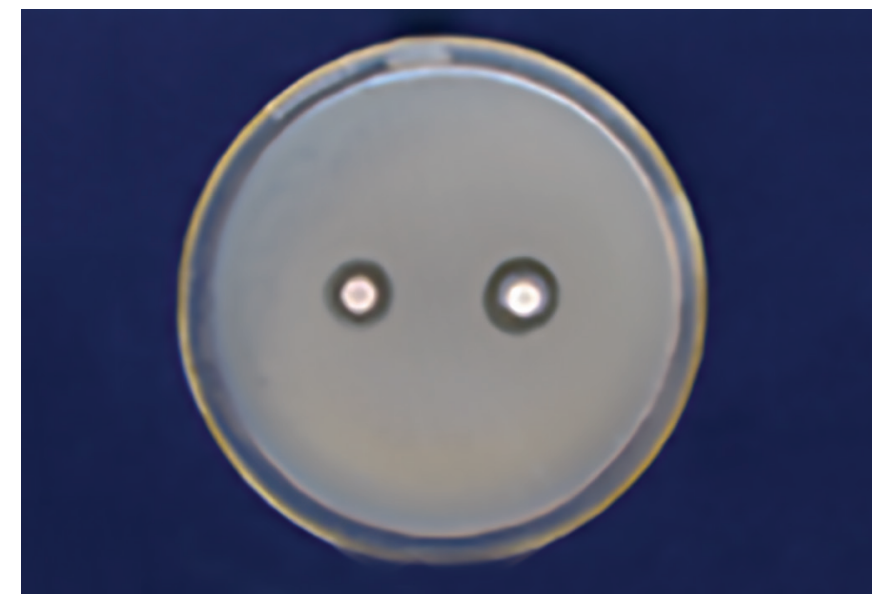

Fig. 2: Manuka honey zone of inhibition $25 \%$ (S. mutans) 
Table 2: Comparison of mean zone of inhibition for S. mutans between Dabur (100\%) and manuka (100\%) honey

\begin{tabular}{llllllr}
\hline Organism & Honey & Mean & Standard deviation & Mean difference & $t$-value & $p$-value \\
\hline \multirow{2}{*}{ S. mutans } & Dabur $100 \%$ & 16.5 & 2.5 & -4.7 & -4.10 & 0.001 \\
& Manuka $100 \%$ & 21.2 & 2.7 & & & \\
\hline
\end{tabular}

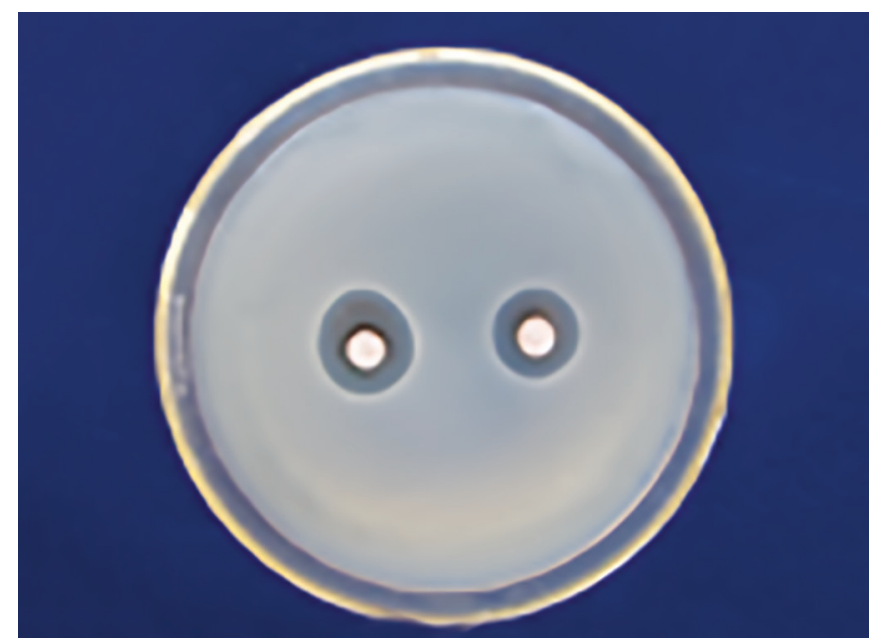

Fig. 3: Dabur honey zone of inhibition 100\% (Lactobacillus)

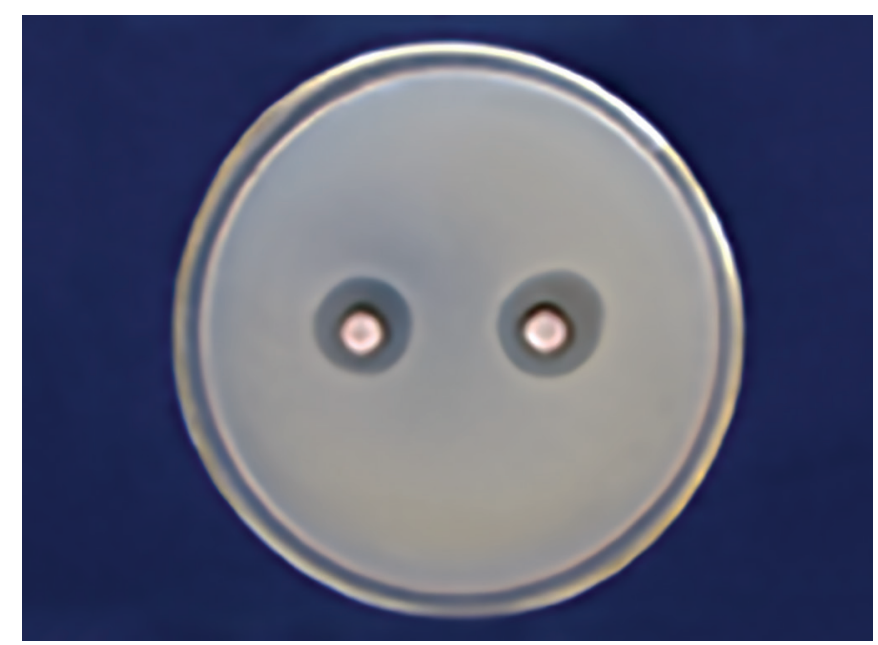

Fig. 4: Manuka honey zone of inhibition $100 \%$ (S. mutans)

Table 3: Comparison of mean zone of inhibition for Lactobacillus between Dabur (25\%) and manuka (25\%) honey

\begin{tabular}{lllllcc}
\hline Organism & Honey & Mean & Standard deviation & Mean difference & $t$-value & $p$-value \\
\hline Lactobacillus & Dabur 25\% & 10.9 & 1.2 & -4.9 & -8.71 & $<0.001$ \\
& Manuka 25\% & 15.8 & 1.3 & & & \\
\hline
\end{tabular}

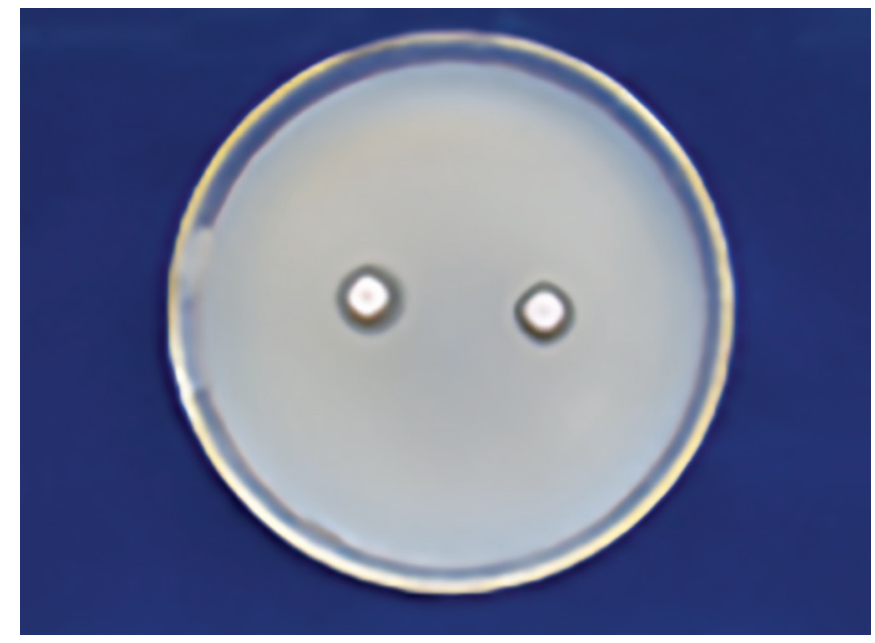

Fig. 5: Dabur honey zone of inhibition 25\% (Lactobacillus)

Table 3 shows that 25\% Dabur honey (Fig. 5) has less inhibitory effect than $25 \%$ manuka honey in Lactobacillus zone (Fig. 6) with a significant $\mathrm{p}$-value $(\mathrm{p} \leq 0.001)$.

Table 4 shows that $100 \%$ of Dabur honey (Fig. 7) has less inhibitory effect than $100 \%$ manuka honey in Lactobacillus (Fig. 8) with a significant $p$-value $(\mathrm{p} \leq 0.001)$.

Similarly, Tables 5 and 6 show that 25\% of Dabur honey has less inhibitory zone than $100 \%$ of Dabur honey in Lactobacillus and Streptococcus zone with a statistical significance $(\mathrm{p} \leq 0.001)$. Tables 7 and 8 show that $25 \%$

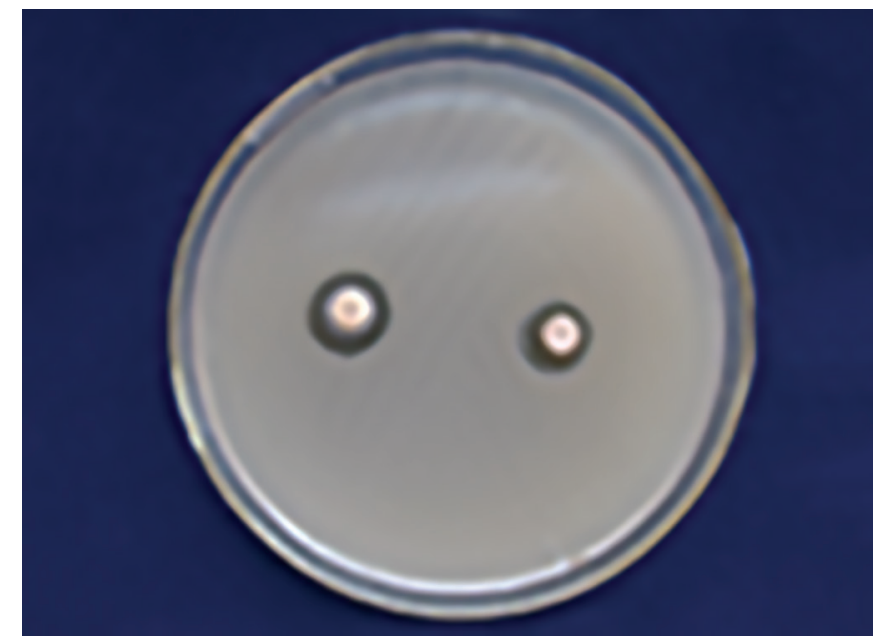

Fig. 6: Manuka honey zone of inhibition 25\% (Lactobacillus)

of manuka honey has less inhibitory zone than $100 \%$ of manuka honey in Lactobacillus and Streptococcus zone with a statistical significance $(\mathrm{p} \leq 0.001)$.

\section{DISCUSSION}

The antibacterial factors of honey are primarily due to enzymatic glucose oxidation reaction, high osmotic pressure, low water activity, acidic environment, high carbonnitrogen ratio, low redox potential, phytochemicals, antioxidants, ${ }^{14-16}$ the hyperosmolarity effect (>80\% sugar 
Table 4: Comparison of mean zone of inhibition for Lactobacillus between Dabur (100\%) and manuka (100\%) honey

\begin{tabular}{lllllll}
\hline Organism & Honey & Mean & Standard deviation & Mean difference & $t$-value & $p$-value \\
\hline Lactobacillus & Dabur 100\% & 17.1 & 2.5 & -5.1 & -4.14 & 0.001 \\
& Manuka 100\% & 22.2 & 3.0 & & & \\
&
\end{tabular}

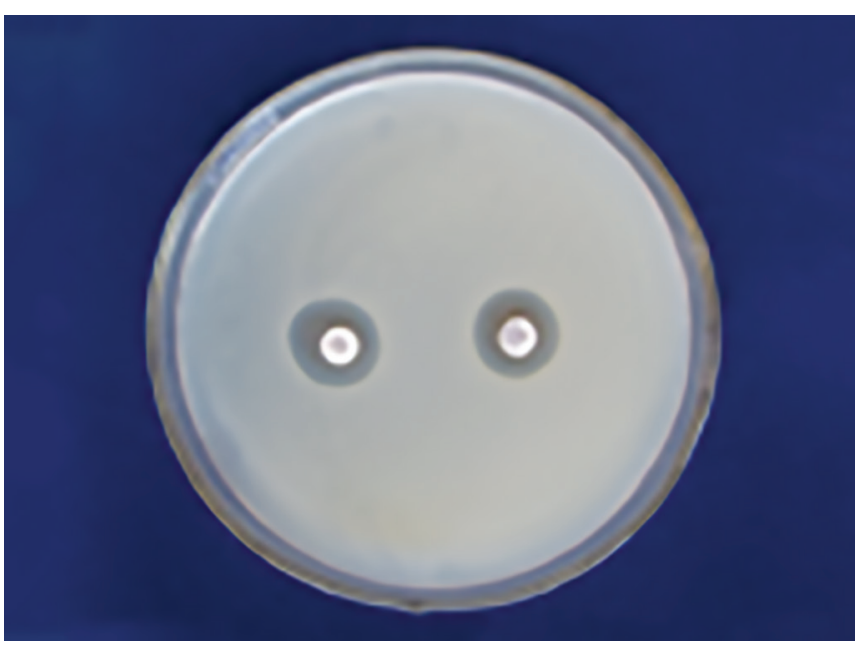

Fig. 7: Dabur honey zone of inhibition $100 \%$ (S. mutans)

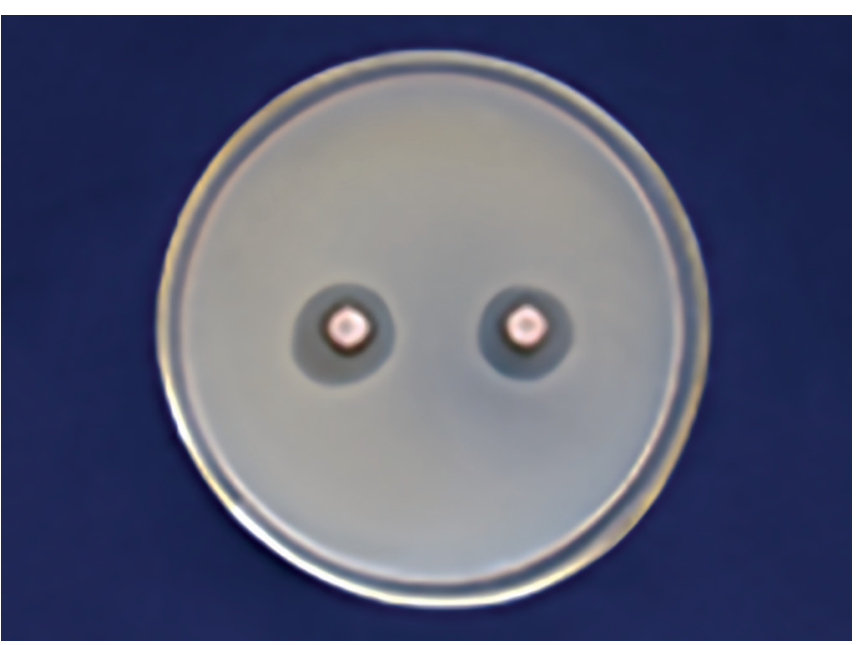

Fig. 8: Manuka honey zone of inhibition 100\% (Lactobacillus)

Table 5: Comparison of mean zone of inhibition for S. mutans between Dabur (25\%) and Dabur (100\%) honey

\begin{tabular}{llllllr}
\hline Organism & Honey & Mean & Standard deviation & Mean difference & $t$-value & $p$-value \\
\hline \multirow{2}{*}{ S. mutans } & Dabur $25 \%$ & 9.8 & 1.5 & -6.7 & -7.4 & $<0.001$ \\
& Dabur $100 \%$ & 16.5 & 2.5 & & & \\
&
\end{tabular}

Table 6: Comparison of mean zone of inhibition for Lactobacillus between Dabur (25\%) and Dabur (100\%) honey

\begin{tabular}{lllllll}
\hline Organism & Honey & Mean & Standard deviation & Mean difference & $t$-value & $p$-value \\
\hline Lactobacillus & Dabur 25\% & 10.9 & 1.2 & -6.2 & -7.1 & 0.001 \\
& Dabur 100\% & 17.1 & 2.5 & & & \\
&
\end{tabular}

Table 7: Comparison of mean zone of inhibition for S. mutans between manuka (25\%) and manuka (100\%) honey

\begin{tabular}{lllllll}
\hline Organism & Honey & Mean & Standard deviation & Mean difference & $t$-value & $p$-value \\
\hline \multirow{2}{*}{ S. mutans } & Manuka 25\% & 14.4 & 1.3 & -6.8 & -7.3 & $<0.001$ \\
& Manuka 100\% & 21.2 & 2.7 & & & \\
\hline
\end{tabular}

Table 8: Comparison of mean zone of inhibition for Lactobacillus between manuka (25\%) and manuka (100\%) honey

\begin{tabular}{lllllll}
\hline Organism & Honey & Mean & Standard deviation & Mean difference & $t$-value & $p$-value \\
\hline Lactobacillus & Manuka 25\% & 15.8 & 1.3 & -6.4 & -6.2 & 0.001 \\
& Manuka 100\% & 22.2 & 3.0 & & & \\
\hline
\end{tabular}

content), acidic $\mathrm{pH}$, hydrogen peroxide, methylglyoxal, bee defensin-1, diverse proteinaceous compounds, flavonoids, and phenolic compounds, ${ }^{4,17,18}$ but the foremost antimicrobial activity of most honeys is due to hydrogen peroxide. $^{19}$

Manuka honey has a phytochemical component and a low hydrogen peroxide component. The nonperoxide antibacterial activity of typical manuka honey was tested against seven species of bacteria and compared with typical honey with a hydrogen peroxide component. The minimum inhibitory concentration (MIC) of honey was found to range from 1.8 to $10.8 \% .^{20}$ Types of honey differ greatly in their antimicrobial potency, varying as much as 100-fold. Manuka honey additionally contains d-gluconolactone, which reduces its $\mathrm{pH}$ and exerts antibacterial property. It also abundantly contains methyl syringate, ortho-methoxyacetophenone, and 3-phenyl lactic acid, all of which inhibit bacterial growth. ${ }^{21,22}$

Methylglyoxal is particularly lethal toward bacterial growth by interrupting cell divisions, arresting growth, and specifically causing the degradation of 
bacterial deoxyribonucleic acid even at a very low concentration. ${ }^{23}$

Rupesh et $\mathrm{al}^{6}$ reported that manuka honey with UMF 15 is highly effective in reducing dental plaque and on the growth of cultures of oral bacteria.

Steinberg et al conducted study, on seven species of oral streptococci and found that the minimum inhibitory concentration of honey for Streptococcus oralis was $12 \%$, for Streptococcus anginosus was 17\%, and for Streptococcus gordonii, Streptococcus mutans, Streptococcus salivarius, Streptococcus sanguis was $25 \% .^{22}$.

English et $\mathrm{al}^{23}$ from their study concluded that the MIC of honey for S. mutans was $25 \%$ and for Streptococcus sobrinus, it was $35 \%$ and that the salivary bacterial count was reduced by $40 \% 1$ hour after holding $5 \mathrm{~mL}$ of honey in the mouth for 4 minutes.

Mandal and Mandal, ${ }^{14}$ and Lin et $\mathrm{al}^{15}$ reported that honey inhibits the growth of a wide range of antibacterial activity on S. mutans and Lactobacillus in vitro. The results of this study are in concurrence with our study.

Oddo et $\mathrm{al}^{24}$ concluded that the use of a low harmful sweetener in the diet is very important, especially if it is confirmed that honey has antibacterial activity against cariogenic bacteria in vitro and in vivo. ${ }^{20}$ The results of this study are similar to that of our study, which is statistically significant.

\section{CONCLUSION}

Natural honey had an antibacterial activity on S. mutans and Lactobacillus bacteria. This effect depends on the concentration of honey used.

Summarizing the findings of our study, we would like to conclude that manuka honey is not as cariogenic as other sugars and has anticariogenic properties. Further research related to manuka honey as a sweetening agent can play a pivotal role in caries prevention, especially in children.

Further studies will be required to substantiate and propagate our preliminary observations.

\section{REFERENCES}

1. Crane, E. Honey: a comprehensive survey. London: William Heinemann Ltd; 1979.

2. Crane, E. History of honey. In: Crane E, editor. Honey, a comprehensive survey. London: William Heinemann; 1975. pp. 439-488.

3. Zumla A, Lulat A. Honey-a remedy rediscovered. J R Soc Med 1989 Jul;82(7):384-385.

4. Rolla G, Loe H, Schiott CR. Retention of chlorohexidine in the human oral cavity. Arch Oral Biol 1971 Sep;16(9): 1109-1116.

5. Yatsunami K, Echigo T. Antibacterial action of honey and royal jelly. Honeybee Sci 1984;5:125-130.
6. Rupesh S, Winnier JJ, Nayak UA, Rao AP, Reddy NV, Peter J. Evaluation of the effects of Manuka honey on salivary levels of mutans streptococci in children: a pilot study. J Indian Soc Pedod prev Dent 2014 Jul-Sep;32(3):212-219.

7. Molan PC. The antibacterial activity of honey: 1 . The nature of the antibacterial activity. Bee World 1992;73(1):5-28.

8. Lin, SM. The effect of manuka honey on enterobacteria. Thesis, Doctor of Philosophy (PhD). The University of Waikato, Hamilton, New Zealand, 2010.

9. Molan PC. The evidence and the rationale for the use of honey as a wound dressing. Wound Pract Res 2011 Dec;19(4): 204-220.

10. Russell KM, Molan PC, Wilkins AL, Holland PT. Identification of some antibacterial constituents of New Zealand manuka honey. J Agric Food Chem 1990 Jan;38(1):10-13.

11. Adcock D. The effect of catalase on the inhibine and peroxide values of various honeys. J Apicult Res 1962 Jan;1(1):38-40.

12. Allen KL, Molan PC, Reid GM. A survey of antibacterial activity of some New Zealand honeys. J Pharm Pharmacol 1991 Dec;43(12):817-822.

13. Kwakman PH, Zaat SA. Antibacterial components of honey. IUBMB Life 2012 Jan;64(1):48-55.

14. Mandal MD, Mandal S. Honey: its medicinal property and antibacterial activity. Asia Pac J Trop Biomed 2011 Apr;1(2):154-160.

15. Lin SM, Molan PC, Cursons RT. The in vitro susceptibility of Campylobacter spp. to the antibacterial effect of Manuka honey. Eur J Clin Microbiol Infect Dis 2009 Apr;28(4):339-344.

16. Al-Mamary M, Al-Meeri A, Al-Habori M. Antioxidant activities and total phenolics of different types of honey. Nutr Res 2002 Sep;22(9):1041-1047.

17. Loe $H$, Schiott $C R$. The effect of mouth rinse and topical application of chlorohexidine on development of dental plaque and gingivitis in man. J Periodontal Res 1970 Apr;5(2):79-83.

18. Jenkins S, Addy M, Wade W. The mechanism of action of chlorhexidine. A study of plaque growth on enamel inserts in vivo. J Clin Periodontol 1988 Aug;15(7):415-424.

19. Decken EM, Maier G, Axmann D, Brecx M, von Ohle C. Effect of xylitol/chlorhexidine versus xylitol/chlorhexidine as single rinses on initial biofilm formation of cariogenic streptococci. Quintessence Int 2008 Jan;39(1):17-22.

20. Daher S, Gulacar FO. Analysis of phenolic and other aromatic compounds in honey by solid-phase micro extraction followed by gas chromatography-mass spectrometry. J Agric Food Chem 2008 Jul;56(14):5775-5780.

21. Bhandary S, Chaki S, Mukherjee S, Das S, Mukherjee S, Chaudhuri K, Dastidar SG. Degradation of bacterial DNA by a natural antimicrobial agent with the help of a biomimetic membrane system. Indian J Exp Biol 2012 Jul;50:491-496.

22. Steinberg D, Kaine G, Gedalia I. Antibacterial effect of Propolis and honey on oral bacteria. Am J Dent 1996 Dec;9(6): 236-239.

23. English HK, Pack AR, Molan PC. The effects of Manuka honey on plaque and gingivitis: a pilot study. J Int Acad Periodontol 2004 Apr;6(2):63-67.

24. Oddo LP, Heard TA, Rodriguez-Malaver A, Perez RA, Fernandez-Muino M, Sancho MT, Sesta G, Lusco L, Vit P. Composition and antioxidant activity of Trigona carbonaria honey from Australia. J Med Food 2008 Dec;11(4):789-794. 